\title{
AQUIFER MODELLING FOR PREDICTING THE EFFECTS OF GROUND-WATER EXPLOITATION
}

Mohd. Saleem ${ }^{1}$, Shobha Ram $^{2} \&$ Gauhar Mahmoo ${ }^{3}$

Abstract-A number of stochastic models have been carried out to predict the effect of ground water exploitation. Most groundwater models are developed for forecasting based on past conditions with the aid of simulations and perform engineering calculations very efficiently. There are also generic models for hypothesis testing. A workflow for groundwater modeling begins with a question that addresses the modeling purpose. In this paper an Improved MODFLOW based Groundwater Flow Modeling is discussed. Estimation of hydraulic conductivity distribution is optimized which are the focus on the distributed parameter (Pressure psia and water rate RB/D).

Keywords: Aquifer modeling, Groundwater modeling, MODFLOW, Pressure, Water rate.

\section{INTRODUCTION}

Groundwater, the term used for water occurring below the ground surface, is an important constituent of hydrological cycle and is the major source of water supply in various sectors. Due to over exploitation, mainly because of high population growth rates and extensive agricultural uses, there has been a growing concern about the water resources. The researchers have been racking their head to improve the ground water quality and quantity. This has been done efficiently and effectively through modeling of aquifer which is a stochastic method of simulating large amounts of water connected to the storage whereby it is not essential to know how the fluid moves in it, but rather how it affects ground water storage [6-8]. There are several aquifer models specially, numerical, Carter-Tracy, Fetkovich, Constant flux, Constant pressure and rainfall.

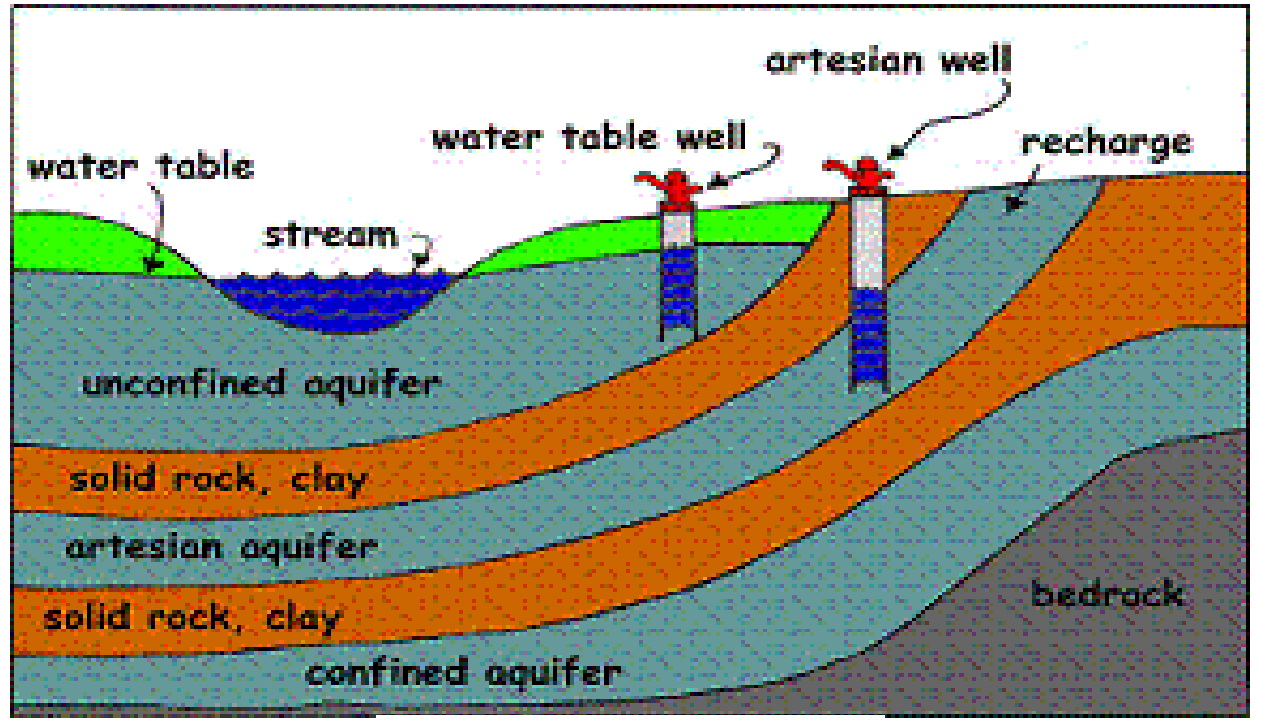

Figure 1: Typical diagram of aquifer

Mostly, aquifer models have their own set of parameters and might be connected to the grid in several directions for examples, top down, bottom up, fault edges and grid edges [1]. To possess better control over which one cell needs to be connected, a sequence of choices may be used to limit the vertical extent and to limit the connections to filtered cells.

\section{MOTIVATION FOR MODELING?}

Why modeling [2][3]? There are the following types of questions which are generally asked to hydrologists about management of groundwater resources as well as groundwater flow systems.

\footnotetext{
${ }^{1}$ University Polytechnic, Jamia Millia Islamia, New Delhi-110025, India

${ }^{2}$ School of Engineering, Gautam Buddha University, Greater Noida- 201308, U.P., India

${ }^{3}$ Department of Civil Engineering, Jamia Millia Islamia, NewDelhi-110025
} 
- How will proposed land use change affect groundwater discharge to wetlands and streams.

- How will pumping affect groundwater levels?

- How will water management decisions related to water diversions affect groundwater levels in the next 50 years?

- How will climate change affect groundwater levels and groundwater discharge to surface water bodies in temperate forests?

- How long will it take for water levels in a lake created as a result of open pit mining to reach equilibrium after dewatering operations cease?

- Where and when should groundwater be sampled to identify potential leakage of a clay liner beneath a landfill?

- What is the capture area of a well field that supplies municipal water?

- How long will it take contaminants leaching into groundwater from an abandoned industrial site to reach the property boundary?

To the better answer of these questions, hydrologists must possess the basic hydro geologic knowledge, insight and professional judgmental ability. They also must have the knowledge of quantitative framework for synthesizing field information and for conceptualizing hydro geologic processes [4][5]. In other words, applying a model is an exercise in thinking and assumptions about the way a system works. For this reason, mathematical modeling should be performed at the beginning of every hydrogeological study that addresses nontrivial questions.

\section{WORK DONE}

Before 1950, the problem of predicting the effects of ground-water exploitation could, in most instances, be solved without considering the total exploitable resources of an aquifer. This was true since in most areas the utilization of ground water was relatively small, and the centers of development were widespread. The procedures then in use for estimating the intake capacity for widely separated ground-water development areas were quite satisfactory.

Scientific research on groundwater recharge and resource assessments have been carried out by Bestow (1971), Sharma et al. (1983, 1991), Farrington (1984), Anson (1985), Sharma and Hughes (1985), Sharma (1986a,b), Sharma and Craig (1989), Thorpe (1989) and Farrington and Bartle (1991). These studies used infiltration tests at selected experimental sites, or naturally occurring isotopes and tracers, to estimate the rainfall recharge to the unconfined aquifers of the Perth Region. These estimates of recharge were made for different landuse and climatic conditions and showed that recharge rates mostly ranged from five per cent to 40 per cent of the rainfall, depending on location and land use.

Many works have been done to improve our understanding of groundwater resources in the Gautam Buddha Nagar region. An important activity has been carried out in the development of groundwater model. At the beginning the model effort was primarily geared towards testing ideas about how the system behaves than for predictive purpose. Many researchers exercised preliminary ground water model to investigate the hydraulic interaction between Hindon river and the surrounding unconfined aquifer and to study the changes in ground water storage of the aquifer in response to fluctuating the water table.

(Baher 1997) tried to improve the knowledge of the interaction between the lake Navaisha and the surrounding aquifers. The researcher developed a model to study the interaction between the lake and ground water, as well as optimize the various aquifer parameters like transmissivity and storage coefficient. He also investigated the ground water storage behavior of the aquifer and inaccurate boundary conditions.

(Hermandez 1999) developed a ground water model which calibrate to estimate the amount of flow from Malawa River to the well field. Its one of the positive remarks is that the model results was evaluated from an environmental point of view. However the validity of the model could not be assured due to scarcity of observations. The Perth Artesian Aquifer model is a quasi three-dimensional, three-layered finite element model using AQUIFEM-N (Townley, 1993) to simulate three major confined aquifers. The Perth Groundwater Resource model integrates the PUWBS model with the Perth Artesian Aquifer model developed by Rust PPK.

Various aquifer models are developed to quantify the water exchange between a lake and groundwater. However, lake levels often show long and short-term transience. Precipitation to and evaporation from the Lake Surface, stream flow, and groundwater fluxes have to be considered. These flow components affect lake levels and changes in them lead to lake level fluctuations (Cheng. 1993).

\section{AQUIFER MODELS}

There have been carried out various modeling of ground water by the researchers. For this purpose some of main aquifer models have been discussed below. There are several popular aquifer models

- Van Everdingen-Hurst (VEH) model

- Carter-Tracy model

- Fetkovich model

- Schilthuis model

- Small- or pot-aquifer model

The first three aquifer models are unsteady state models and are the most realistic one. They attempt to simulate the complex pressure changes that gradually occur within the aquifer [9]. The unsteady-state models are far more successful at capturing the real dynamics than other models. The pressure interaction causes the water influx rate to start at zero, grow steadily, reach a maximum, and then dissipate. While, steady-state model assumes the aquifer pressure remains constant. Charts or tables 
had to be consulted repeatedly to execute a single calculation. To address this limitation, we address an alternative that is free of tables and charts. This model, however, is only approximations and simplifications of the VEH model [14].

\section{MODFLOW BASED GROUNDWATER FLOW AQUIFER MODELING}

1. This model development consists of converting the conceptual model of aquifers to a numerical model of groundwater flow using Visual MODFLOW [10-13]. The governing equation for density-dependent groundwater flow model in terms of freshwater head, which is solved by MODFLOW routines in the SEAWAT code. The governing water balance equation in MODFLOW allowing for 3D flow for an unconfined aquifer is given as

$$
\frac{\partial}{\partial x}\left(K_{x} h \cdot \frac{\partial \mathrm{h}}{\partial \mathrm{x}}+\frac{\partial}{\partial \mathrm{y}}\left(\mathrm{K}_{\mathrm{y}} \mathrm{h} \cdot \frac{\partial \mathrm{h}}{\partial \mathrm{y}}\right)=-S_{y} \frac{\partial \mathrm{h}}{\partial \mathrm{t}}-R\right.
$$

where: $\mathrm{Kx}, \mathrm{Ky}=$ are directional components of hydraulic conductivity

Sy $=$ specific yield

$\mathrm{R}=$ general sink/source term

$\mathrm{h}=$ head

$\mathrm{t}=$ time

Estimation of hydraulic conductivity distribution is optimized by using a combination of trial and error. This distributed parameter model consists of five cells representing each of the watersheds contributing recharge to the aquifer. Transient simulation is carried out for a 10-yr period (2005-15). The objective of this model is to simulate spring discharge. The impact of the amount of pumping on a regional scale on spring discharge can be evaluated using a lumped parameter model; however, more detailed evaluation of the effect of pumping on groundwater levels and spring discharge requires a distributed parameter modeling approach [15].

2. Aquifer performance parameter

The aquifer performance is described in terms of the:

- Delivery rate

- Average aquifer pressure

- Cumulative water-influx volume as a function of time

The aquifer pressure characteristically lags behind the reservoir pressure and is estimated by

$$
\bar{p}_{a}=p_{i}-\frac{W_{e}(t)}{c_{t} V_{p a}} .
$$

Here aquifer delivery rate is given by $\mathrm{q}_{\mathrm{w}}=\partial \mathrm{W}_{\mathrm{e}}(\mathrm{t}) / \partial \mathrm{t}$

Which is determined from the slope of the $\mathrm{W}_{\mathrm{e}}$ vs. $\mathrm{t}$ curve.

\section{RESULT AND DISCUSSION}

The water-delivery rate is initially zero and increases rapidly. It peaks after approximately 12 to 14 years and then slowly decreases. The aquifer and reservoir pressures start at equivalent values. The reservoir pressure declines more quickly than the aquifer pressure. The pressure differential between the aquifer and reservoir grows and is approximately 250, 350, and 500 psia, respectively, after 2, 5, and 10 years. The pressure differential peaks after 12 to 14 years and then begins to dissipate. The pressure differential and delivery rate decline together.

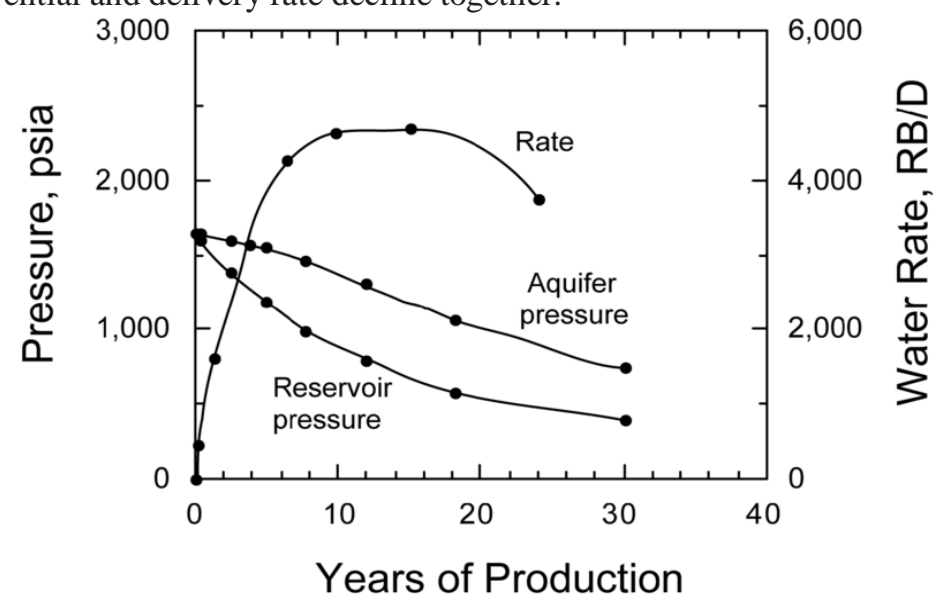

Fig. 2 - Predicted aquifer pressure and water-influx rate histories for example

The aquifer performance noted in Fig. 2 is not without exception. The qualitative performance in Fig. 2 is characteristic of an initially saturated reservoir. Aquifers feeding initially undersaturated reservoirs may behave quite differently. The difference 
stems from the difference in the reservoir pressure histories. The reservoir pressure in initially under saturated oil reservoirs initially declines much more quickly than in initially saturated reservoirs. This large pressure differential, in turn, promotes water influx; consequently, the water-influx rate increases more rapidly in initially undersaturated reservoirs than initially saturated reservoirs. Once the bubblepoint is reached, the pressure differential between the aquifer and reservoir may decline temporarily. Later, the pressure differential may increase, reminiscent of an initially saturated reservoir, as in Fig. 2 The net effect is that water recharge rate may oscillate in an initially undersaturated

\section{REFERENCES}

[1] Anderson, M.P. and Woessner, W.W., 1992. Applied Groundwater Modeling, Academic Press, Inc., San Diego, CA., $381-87$.

[2] American Society for Testing and Materials, 1993. Standard Guide for Application of a Ground-Water Flow Model to a Site Specific Problem, ASTM Standard D 5447-93, West Conshohocken, PA, 6 p.

[3] American Society for Testing and Materials, 1995. Standard Guide for Subsurface Flow and Transport Modeling, ASTM Standard D 5880-95, West Conshohocken, PA, 6 p.

[4] Bear, J. and Verruijt, A., 1987. Modeling Groundwater Flow and Pollution, D. Reidel Publishing Company, 414 p.

[5] Franke, O.L., Bennett, G.D., Reilly, T.E., Laney, R.L., Buxton, H.T. and Sun, R.J., 1991. Concepts and Modeling in GroundWater Hydrology -- A Self-Paced Training Course, U.S. Geological Survey Open-File Report 90-707.

[6] Kashyap, Deepak, 1989. Mathematical Modelling for Groundwater Management - Status in India, Indo-French Seminar on Management of Water Resources, 22-24 September, 1989, Festival of France-1989, Jaipur, pp. IV-59 to IV-75.

[7] Kumar, C. P., 1992. Groundwater Modelling - In. Hydrological Developments in India Since Independence, A Contribution to Hydrological Sciences, National Institute of Hydrology, Roorkee, pp. 235-261

[8] Anderson, M.P., Woessner, W.W., 1992. Applied Groundwater Modeling, Simulation of Flow and Advective Transport, Academic Press, New York, p. 381.

[9] Hovorka, S.D., Mace, R.E., Collins, E.W., 1998. Permeability structure of the Edwards aquifer, South Texas-Implications for aquifer management. University of Texas at Austin, Bur. Econ. Geol., Rep. Inv. No. 250, p. 55.

[10] Hsieh, P.A., Freckleton, 1993. Documentation of a computer program to simulate horizontal-flow barriers using the US Geological Survey's modular three-dimensional finite-difference ground-water flowmodel.USGeol.Surv.,OpenFileRep.92-477.

[11] Kuniansky, Eve L., and Holligan, Kelly Q. (1994). Simulations of Flow in the Edwards-Trinity Aquifer System and Contiguous Hydraulically Connected Units, West-Central Texas. Austin: US Geological Survey, Water-Resources Investigations Report 93-4039.

[12] Klemt, William B., Knowles, Tommy R., Elder, Glenward R., and Sieh, Thomas W. (1979). Ground-Water Resources and Model Applications for the Edwards (Balcones Fault Zone) Aquifer in the San Antonio Region, Texas. Austin: Texas Department of Water Resources, Report 239.

[13] Maclay, R. W., and Land. L. F. (1988). Simulation of Flow in the Edwards Aquifer, San Antonio Region, Texas, and Refinement of Storage and Flow Concepts. Washington: US Government Printing Office, US Geological Survey Water-Supply Paper 2336-A.

[14] McCarl, Bruce A., Jordan, Wayne R., Williams, R. Lynne, Jones, Lonnie L., and Dillon, Carl R. (1993). Economic and Hydrologic Implications of Proposed Edwards Aquifer Management Plans. College Station: Texas Water Resources Institute, Technical Report No. 158.

[15] LBJ-Guyton Associates, (2005). HSPF Recharge Models for the San Antonio Segment of the Balcones Fault Zone Edwards Aquifer. EAA Contract 02-87-AS. 